Saudi Journal of Business and Management Studies Abbreviated Key Title: Saudi J Bus Manag Stud ISSN 2415-6663 (Print) |ISSN 2415-6671 (Online) Scholars Middle East Publishers, Dubai, United Arab Emirates Journal homepage: http://scholarsmepub.com/sjbms/

Original Research Article

\title{
The Effect of Life Insurance Business's Income on the Economic Growth of Nigeria
}

\author{
Yinka Augustine $\mathrm{SOYE}^{1 *}$, Omoniyi Oladipupo AGBOOLA ${ }^{2}$ \\ ${ }^{1}$ Insurance Department, School of Management Studies, the Federal Polytechnic, Ilaro, Ogun, Nigeria \\ ${ }^{2}$ Post-Graduate Student Business Administration Department, Faculty of Environment, Social and Management Sciences, Lead City University, Ibadan, \\ Nigeria
}

DOI: $10.36348 /$ sjbms.2019.v04i12.006 $\quad$ | Received: 20.11.2019 | Accepted: 27.11.2019 | Published: 20.12.2019

*Corresponding author: Yinka Augustine SOYE

Abstract

For any economy to experience speedy and rapid growth, a viable and effective insurance industry is required. So, it is important for insurance business within the financial institution to be given priority by the government if vibrant and robust economic growth is expected. Hence, this study investigated the effect of life insurance business's income on the economic growth of Nigeria. Using secondary data sourced from the Central Bank of Nigeria (CBN) Statistical Bulletin and Nigeria Insurers Digest, from the period of 1990 to 2017, the study adopted the Pearson correlation analysis (ordinary) and ordinary least square (OLS) regression technique to analyze the data and test the study's hypotheses respectively. The findings show that exchange rate, foreign direct investment, and life insurance business have really impacted and influenced the growth of Nigeria economy within the period under investigation. But, the study reveals that inflation rate has negative relationship with economic growth of the country.

Keywords: Life Insurance, Inflation, Economic Growth, FDI, Exchange Rate.

Copyright @ 2019: This is an open-access article distributed under the terms of the Creative Commons Attribution license which permits unrestricted use, distribution, and reproduction in any medium for non-commercial use (NonCommercial, or CC-BY-NC) provided the original author and source are credited.

\section{INTRODUCTION}

The huge potential of growth and development commensurate with the population of Nigerian citizens has not been exploited by the financial institutions, especially the insurance industry since the nation become sovereign state. The utmost proximate reason that accounted for this is the level of knowledge about the importance of insurance policies in Nigeria, precisely life insurance policies to household coverage and investment; and to the economic growth and development. These are influencing by high rate of illiteracy component of each society dominating in country. One of the problems associated with low contribution of insurance business to economic growth (GDP) in Nigeria is the misconception of the benefits of life insurance to our social environmental development. Olagbegi [1] opines that the low orientation about insurance business in Nigeria is a prominent factor that influences the rate of patronage. Thus, globally is one of the lowest insurance markets. Agabi [2] aver that many Nigerians lack the in-depth understanding of the enormous benefits offer by life insurance products, and many decided not to patronize life insurance business because of irregular payment by many insurers. In Nigeria, based on the nation's experience of stunted growth; the insurance business has not actually contributed effectively and meaningfully in its role as one of the economy financial in mobilizing funds for productive investment which could lead to economic growth and development. Also, insurance companies are not encouraged in discharging their duties as bedrock to the economy growth and sustainability, and a propeller of vibrant economy driving. However, against this background, this study stands to examine the effect of life insurance business on economic growth in Nigeria. therefore, the specific objectives for this study are: to determine the significant impact of life insurance premium on the economic growth of Nigeria; to ascertain the significant impact of inflation rate on the economic growth of Nigeria; to investigate the significant impact of interest rate on the economic growth of Nigeria; and to establish the significant 
impact of exchange rate on the economic growth of Nigeria.

\section{Conceptual Framework \\ Concept of life insurance}

Life insurance is a social economic tool that is vital for the protection of social vices. Beck and Webb [3] asserted that life assurance products render some financial services to individuals and the economy as a whole. It is also a financial tool for dealing with risk associated with economic activities of individuals in the societies. Life insurance is a saving mechanism that allows individuals and organizations to save against future adversities. In the view of Madukwe and Anyanwaokoro [4] life insurance is a social scheme that prevent against the adverse effect of economic misfortune, which may arise as a result of the death or disability of a breadwinner in the family. Therefore, life insurance products are saving tools that provide saving mediums for the consumers, and enhance saving culture in the economy.

\section{Economic Growth}

Economic growth is the positive increase in per capital gross domestic activities of a country within a specific period of time, usually a year. Okpara [5] in his study defined economic growth as the increase in the amount of goods and services produced in an economy which is measured by positive changes in a country's gross domestic product. It is often measured as the rate of change in real GDP [6]. Negative growth can be referred to by saying that the economy is shrinking. This is characterized with economic recession and economic depression. The economic growth is helpful to increase the incomes of the society; it helps the nation to bring the unemployment at low level; also helpful in the deliveries of public services; and assist in the allocation of national resources.

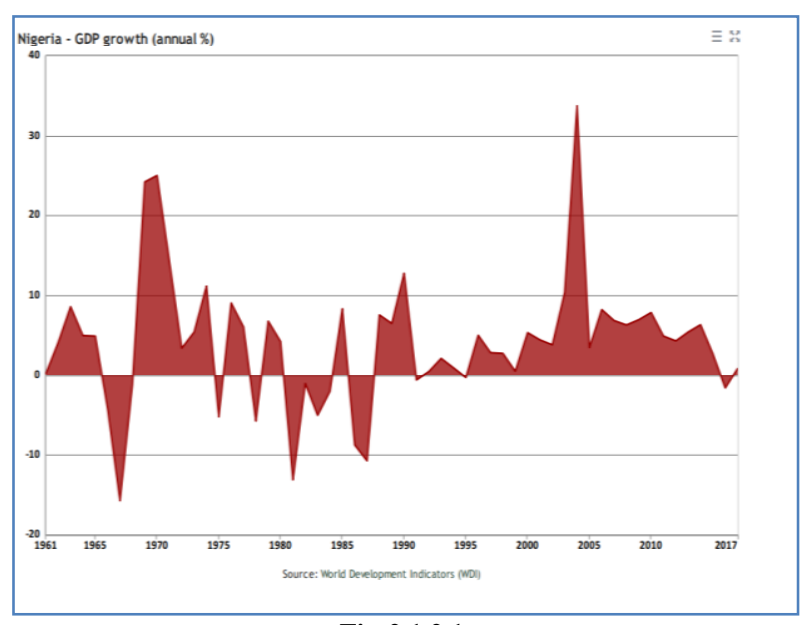

Fig-2.1.2.1

Economic growth has to do with policies intended to transform and restructure of the real economic sectors in the country [6].

\section{Theoretical Framework}

Challenges of insurance business in Nigeria

Insurance business is a vital financial tool, but understated within the economy of Nigeria due to lack of public awareness and sensitization among the citizens. Ujunwa and Modebe [7] in their study expressed that despite the long history of insurance industry in Nigeria, the sector's operational efficiency has remained sub-optimal. There were attributed to factors such as unfavorable macroeconomic environment, poor regulatory framework, market suspicion of insurance companies among others. Babalola [8] as cited in Ujunwa and Modebe [7] contended that insurance industry "reduces the effects of risks and positively relates to growth as entrepreneurs insure their exposures, otherwise riskassuming abilities are hindered".

\section{Life Insurance and Economic Growth}

Life insurance business is the financial tool mechanism that create enable channel for funds to be invested in the economy. Madukwe and Anyanwaokoro [4] opined that Life insurance companies act as a vehicle for the mobilization of savings for long term investment purpose, leading to economic growth and development. Therefore, it is imperative to highlight that life insurance sector plays a critical role in any economy through its mechanism of promoting savings by the way of life policies, and hence fostering intermediation [9]. Moreover, life insurance business is a financial thrift stimulator tool that influences every individual that would not ordinarily contribute or save at the expense of their immediate pleasure for their future social risk. According to Beck and Webb [3] life insurance policies give a means for disciplined contractual saving and have become effective as instruments for boosting huge amounts of savings in the economy. Such funds can be used to purchase the equity of other companies, which per capital will be used by such firms to buy equipments, plants, and other technological innovations, resulting in those companies realizing economies of scale and thereby increasing their output [9].

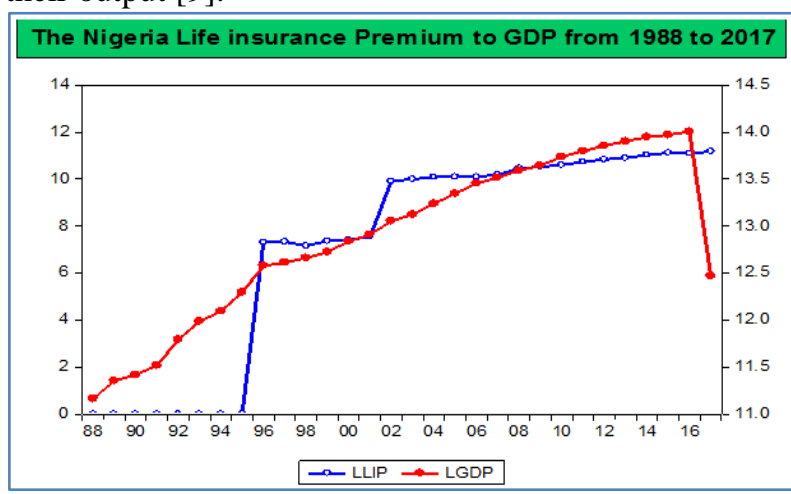

Fig-2.2.2.1

Source: Author 2019 


\section{Inflation and economic growth}

Inflation is the persistent rise in the price of goods and service to a long period of time. It is a situation in the economy where much amount of money is used to purchase view items. According to Hamilton [10] inflation has been widely described as an economic situation when the increase in money supply is 'faster' than the new production of goods and services in the same economy. Inflation in the economy is evaluated through consumer price index (CPI), although there are other methods to measure inflation in the economy, but this study mentioned the CPI because it stand for the cost of living in the economy and is, therefore, more suitable for evaluating the welfare of the citizens. Moreso, CPI is useful for monetary policy in the economy because of its frequent availability. However, inflation rate in Nigeria is determined by unfavorable exchange rate, when import is higher than export, and rate of money supply in the economy. All these will invariably affect the economy.

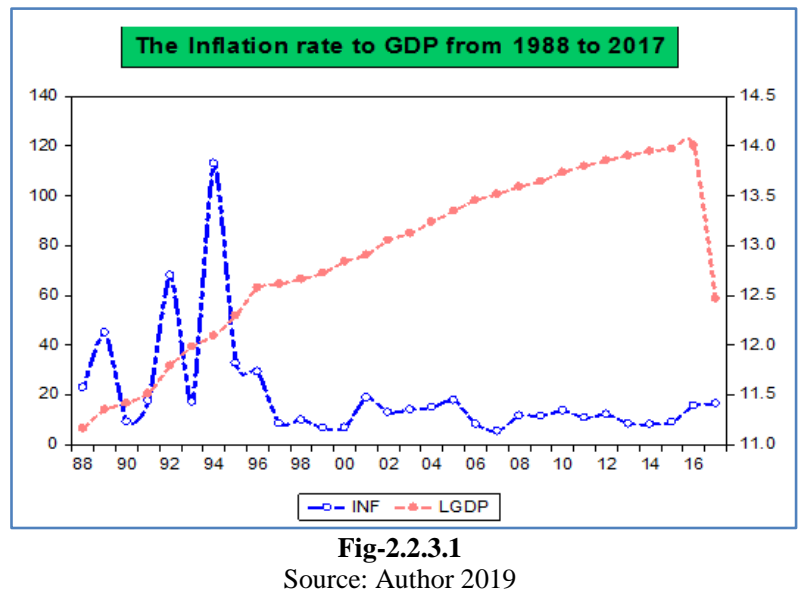

\section{Exchange Rate and Economic Growth}

Exchange rate is the price of currency of a particular country that determines its transactions with another country. Exchange rate is the price mechanism that establishes and influences the economic relationship between one country and the other. Exchange rate establishes the relative prices of national and international goods, as well as the strength of foreign investor participation in the international trade [11]. Hossain [12] in his study averred that exchange rate assists to bond the price systems of two different countries by making it possible for international trade to exist, and also affects the volume of imports and exports, as well as balance of payments position of the country. This means that the economic growth of a country has no choice but depends on its real exchange rate with other countries. Aliyu [7] established in his study that appreciation of exchange rate will result in increase of imports and reduces export, while depreciation of exchange rate would expand export and discourage import. This indicates that when there is moderate depreciation of exchange rate in a country, it will positively influence the economic activities, and this would strongly reflects on the financial sector, especially in the insurance business, because citizen would obtain different insurance covers against their business risks, it will also have enormous multiplier effects on the contribution of insurance industry to the economic growth. As a result, exchange rate is one of the external pillars of a nation that influences its economic growth. This is so, according to Chichi and Casmir [13] exchange rate plays an important role in international economic business because no country can remain in isolation due to natural resources endowment. However, the economic determinants which influence the foreign exchange rate include: balance of payments; economic growth; money supply; inflation rate; unemployment rate etc. Therefore, sustainability of economic growth depends on the foreign exchange rate [14].

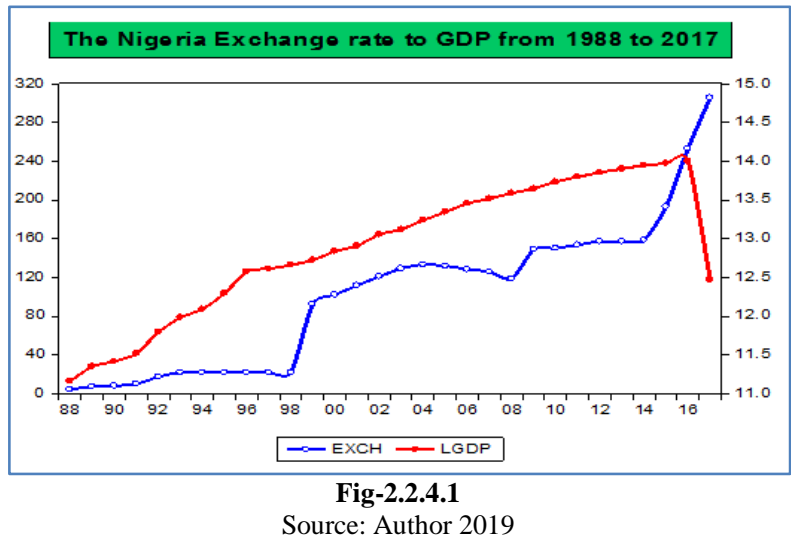

Interest Rate and Economics Growth

The primary function of interest rate is to influence the mobilization of financial resources, and to ensure efficient utilization of the resources for economic growth and development promotion [15]. Interest rate is macroeconomic growth factor, which is very prone to the risk of volatility. Its fluctuation nature (high and low rates) impacts the economic prosperity of a country, and extends to influence its economic growth rate.

The insurance companies channel revenue accrued from risk pooling services rendered to the insuring public to finance the economic activities through their investment in real and financial assets of the country. Interest rate in any environment affects demand by both existing and prospect insured for certain insurance policies. The life insurance companies are exposed to the interest rate environment because they transact long-term businesses whose present values depend on the country's interest rates [16]. Therefore, it is very imperative for insurers to effectively predict interest rate trends in the economy. Insurance firms earn high interest income when interest rates are high and on the contrary high interest rates discourage premiums. The investment operations of insurers play an important role in overall financial performance. 


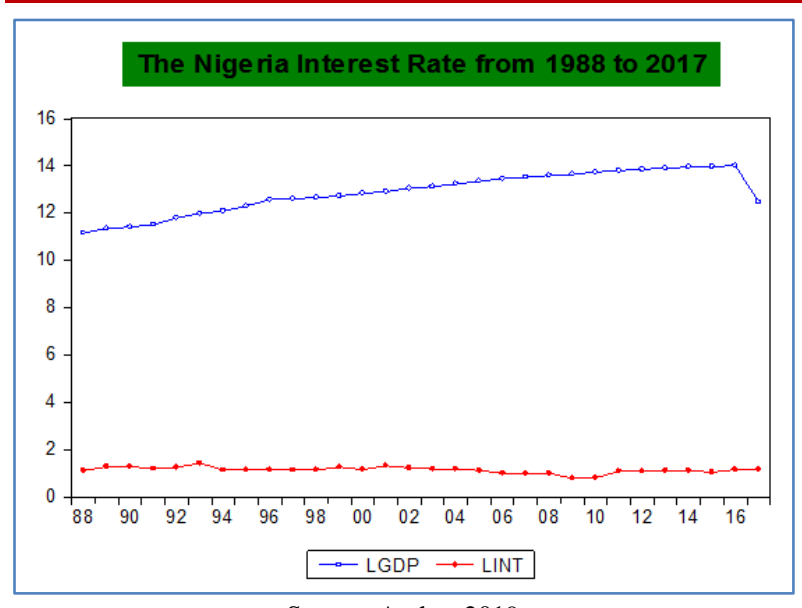

Source: Author 2019

Fig-2.2.5.1

\section{Modern Theory of Financial Intermediation}

Insurance companies collect premiums from their customers, and later reinvest these premiums, especially life insurance premium to the economy. Insurance organizations do these basically to secure funds that would help to meet their financial obligations. This can be possible as a result of integrity or trust placed on them by their clients; effectively operating on cost effective manner; and transparency to the shareholders.

Merton and Bodie [17] propounded a theory called modern theory of financial intermediation which encompasses traditional theory and the changes in financial organization. The theory emphatically states that insurance business provides: the medium for clearing and payments settling to facilitate goods and services exchange; mechanism for pooling together of resources; allocation of resources; tools for risk management; price data to help in organizing decentralized policy making in different sectors of the economy; and the means to mitigate the problem of hazards.

\section{Empirical Review}

Okolo and Ani [18] studied on insurance premium, FDI and GDP, using two-stage least square technique and correlation matrix. The study shows that Insurance premium contributed to the growth of foreign direct investment in Nigeria. However, it reveals that foreign direct investment was insignificant with respect to gross domestic product. The study recommended that Nigerian government should consider the future effect of present policies, and gear toward increasing foreign direct investment and economic growth in the country.

Adeniran, Yusuf, \& Adeyemi [11] conducted research on the impact of exchange rate fluctuation on the Nigerian economic growth: using correlation and regression analysis of the ordinary least square (OLS) to analyze their data. The result of the study revealed that exchange rate has positive impact on economic growth, but there is no significant relationship between the two variables. Also, the study established that interest rate and rate of inflation have negative impact on economic growth, but they have no significant relationship with economic growth respectively. Therefore, the study recommends that government should promote export strategies in order to maintain a good balance of trade and also favorable environment, as well as infrastructural facilities to attract foreign investors to invest their businesses in Nigeria.

Chichi and Casmir [13] investigated on exchange rate and the economic growth in Nigeria, adopting the Ordinary Least Square (OLS) method of estimation to analyze data covering the period from 2000 to 2010 . The results of the study show that there is a short-run relationship between exchange rate, inflation rate, interest rate and GDP in Nigeria within the period of study.

Obanuyi [19] carried out study on the nexus between interest rate and Nigeria economic growth. The study adopted co-integration and error correction modeling techniques. The study showed that lending rates have significant effect on Nigeria economic growth. The study established that the necessary policies for promoting economic growth needs to be formulated and properly implemented.

Umaru and Zubairu [20] examined the impact of inflation on economic growth and development in Nigeria within the period of 1970 to 2010, using Unit root and Granger Causality tests to perform the stationarity status of the variables and direction of causation respectively. The study reveals that inflation has a positive impact on economic growth by encouraging productivity in addition to the evolution of total factor productivity. The study then concludes that policymakers should make effort to increase output level in Nigeria by improve productivity in the country.

\section{METHODOLOGY}

This study adopted ex-post facto research design to evaluate how the selected explanatory variables have contributed to the economy growth of Nigeria. The research design is an Ex-post facto research design because the study makes use of published existing data. Basler [20] stated in his study that ex-post facto is a Latin word connotes 'from after the fact' and relies on the study of relationships among variables as they occur naturally without any modification from the researcher. For this study secondary data is sourced from the Central Bank of Nigeria $(\mathrm{CBN})$ released Statistical Bulletin, Nigeria Insurers Digest report, and other financial reports related to the study. Thirty (30) years (1988 - 2017) economic indicators including life insurance premium data from 1988- 2017 are analyzed to explore their contributions to economic growth in Nigeria. Spearman rank-order correlation and ordinary least square (OLS) techniques are used to analyze the collected data for the 
Yinka Augustine SOYE \& Omoniyi Oladipupo AGBOOLA; Saudi J Bus Manag Stud, Dec., 2019; 4(12): 898-906

research. Spearman rank-order correlation establishes the relationship that exists between the dependent variable and independent variables considered for the study. OLS technique was employed to ascertain the present and predictability relationship between dependent variable and independent variables under study. Econometric views (E-views 9) statistical package was used to carry out this analysis.

Table-1: Descriptions of Dependent and Independent Variables

\begin{tabular}{|l|l|l|l|l|}
\hline Notation & $\begin{array}{l}\text { Dependent } \\
\text { Variable }\end{array}$ & Description & $\begin{array}{l}\text { Independent } \\
\text { Variables }\end{array}$ & Description \\
\hline $\boldsymbol{Y}$ & $\begin{array}{l}\text { Gross Domestic } \\
\text { Product }\end{array}$ & $\begin{array}{l}\text { Natural Log of } \\
\text { Gross premium }\end{array}$ & & \\
\hline $\boldsymbol{X} \mathbf{X}$ & & & Exchange rate & As extracted \\
\hline $\boldsymbol{X} \mathbf{X}$ & & & Inflation rate & As extracted \\
\hline $\boldsymbol{X}$ & & & Interest rate & Natural log of interest rate \\
\hline $\mathbf{4}$ & & $\begin{array}{l}\text { Life Insurance } \\
\text { Premium }\end{array}$ & $\begin{array}{l}\text { Natural log of Life Insurance } \\
\text { Premium t }\end{array}$ \\
\hline
\end{tabular}

\section{Analysis of data}

Table-2: Data Used For Analysis

\begin{tabular}{|l|l|l|l|l|l|}
\hline & Lgdp $(Y)$ & Exch $\left(\boldsymbol{x}_{\mathbf{1}}\right)$ & Inf rate $\left(\boldsymbol{x}_{\mathbf{2}}\right)$ & Lint rate $\left(\boldsymbol{x}_{\mathbf{3}}\right)$ & Llip $\left(\boldsymbol{x}_{\mathbf{4}}\right)$ \\
\hline 1988 & 11.1621 & 4.54 & 22.92 & 1.11 & N/A \\
\hline 1989 & 11.3518 & 7.36 & 45.04 & 1.27 & N/A \\
\hline 1990 & 11.4160 & 8.04 & 9.29 & 1.27 & N/A \\
\hline 1991 & 11.5160 & 9.91 & 17.60 & 1.19 & N/A \\
\hline 1992 & 11.7924 & 17.30 & 68.06 & 1.24 & N/A \\
\hline 1993 & 11.9856 & 22.07 & 26.13 & 1.42 & N/A \\
\hline 1994 & 12.0924 & 22.00 & 113.08 & 1.13 & N/A \\
\hline 1995 & 12.2962 & 21.90 & 32.73 & 1.13 & N/A \\
\hline 1996 & 12.5774 & 21.8861 & 29.3 & 1.13 & 7.3139 \\
\hline 1997 & 12.6140 & 21.8861 & 8.5 & 1.13 & 7.3381 \\
\hline 1998 & 12.6617 & 21.8861 & 10 & 1.13 & 7.1606 \\
\hline 1999 & 12.7249 & 92.6934 & 6.6 & 1.26 & 7.3651 \\
\hline 2000 & 12.8387 & 102.1052 & 6.9 & 1.15 & 7.4302 \\
\hline 2001 & 12.9103 & 111.9433 & 18.9 & 1.31 & 7.5474 \\
\hline 2002 & 13.0543 & 120.9702 & 12.9 & 1.22 & 9.9176 \\
\hline 2003 & 13.1239 & 129.3565 & 14 & 1.18 & 10.0055 \\
\hline 2004 & 13.2386 & 133.5004 & 15 & 1.18 & 10.0861 \\
\hline 2005 & 13.3477 & 132.1470 & 17.9 & 1.11 & 10.1120 \\
\hline 2006 & 13.4573 & 128.6516 & 8.2 & 1 & 10.1053 \\
\hline 2007 & 13.5185 & 125.8331 & 5.4 & 0.98 & 10.1982 \\
\hline 2008 & 13.5928 & 118.5669 & 11.6 & 0.99 & 10.4673 \\
\hline 2009 & 13.6463 & 148.8802 & 11.5 & 0.78 & 10.5352 \\
\hline 2010 & 13.7373 & 150.2980 & 13.7 & 0.8 & 10.6016 \\
\hline 2011 & 13.7992 & 153.8616 & 10.8 & 1.08 & 10.7369 \\
\hline 2012 & 13.8556 & 157.4994 & 12.2 & 1.08 & 10.8449 \\
\hline 2013 & 13.9036 & 157.3112 & 8.5 & 1.11 & 10.9053 \\
\hline 2014 & 13.9496 & 158.5526 & 8.1 & 1.11 & 11.0357 \\
\hline 2015 & 13.9738 & 193.2792 & 9.01 & 1.04 & 11.1028 \\
\hline 2016 & 14.0064 & 253.4923 & 15.7 & 1.15 & 11.1834 \\
\hline 2017 & 12.4680 & 305.8256 & 16.5 & 1.15 & \\
\hline & & & \\
\hline
\end{tabular}

Sources: CBN Statistical Bulletin, 2018; CBN Annual Report and Statement of Accounts (Various Issues); CBN Money and Credits Statistics, (2013, 2015, 2017). And Nigeria Insurance Digest (2002 - 2016) 
Regression Analysis

$: L G D P=a_{0}+E X C H_{\beta 1}+I N F_{\beta 2}+L L I P_{4}+L I N T+\mu$

Where:

LGDP $=\log$ of gross domestic product

$\mathrm{EXC}=$ exchange rate

$\mathrm{INF}=$ inflation rate

$\mathrm{LINT}=\log$ of interest rate

$\mathrm{LLPR}=\log$ of life insurance premium

\section{Unit root test}

The unit root test was carried out before the regression analysis; the unit root test was performed to confirm the stationary properties of the data considered for the study.

Table-3: Unit root table

\begin{tabular}{|l|l|l|l|l|l|}
\hline variables & $\begin{array}{l}\text { ADF t-statistic } \\
\text { at difference }\end{array}$ & $\begin{array}{l}\text { ADF t-statistic } \\
\text { Value }\end{array}$ & $\begin{array}{l}\mathbf{5 \%} \\
\text { critical value }\end{array}$ & Probability & $\begin{array}{l}\text { Order of } \\
\text { integration }\end{array}$ \\
\hline LINT & $1^{\text {st }}$ & -6.647191 & -3.580623 & 0.0000 & $1(2)$ \\
\hline LINF & $1^{\text {st }}$ & -10.56882 & -3.622033 & 0.0000 & $1(2)$ \\
\hline LGDP & $2^{\text {nd }}$ & -1.723415 & -1.953858 & 0.0802 & $1(0)$ \\
\hline LLPR & $2^{\text {nd }}$ & -26.64012 & -3.644963 & 0.0000 & $1(2)$ \\
\hline LEXC & $2^{\text {nd }}$ & -3.940498 & -1.955020 & 0.0004 & $1(0)$ \\
\hline
\end{tabular}

The results of the unit root tests based on the Augmented Dickey-Fuller (ADF) tests are presented in Table 3.3 the data is said to be stationary (i.e. has no unit root) if the t-statistic greater than the critical values in an absolute term and the p-value should be significant $(p<0.05)$. The results show that, interest rate has no stationary problem because the ADF statistic (to) 6.647191 at $1^{\text {st }}$ difference is greater than the critical values of 3.56882 in absolute term at $5 \%$ level of significant with the $\mathrm{P}$-value of 0.0000 , as a result integrated of the order two 1(2). The inflation rate (INF) is stationary at $1^{\text {st }}$ difference because the ADF statistic (ta) 10.59594 is greater than the critical values of 3.622033 in absolute term at 5\% level of significant with the $\mathrm{P}$-value of 0.0000 , as a result integrated of the order two 1(2). The GDP is not to be stationary (had a unit root problem) at all levels because the ADF statistic (ta) 1.723415 is lesser than the critical values of 1.95 3858 at all the levels of significant $(5 \%)$ and the P value of 0.0802 is not significant, so it was integrated of the order I (0). The life insurance premium (LLIP) has no stationary issue because the ADF statistic (t $\alpha$ ) 26.64012 at $2^{\text {nd }}$ difference is greater than the 3.644963 critical values in absolute term at $5 \%$ level of significant with the $\mathrm{P}$-value of 0.0000 , as a result integrated of the order one 1(2). Lastly, exchange rate $(\mathrm{EXCH})$ has no stationary problem because the ADF statistic (t $\alpha$ ) 3.940498 at $1^{\text {st }}$ difference is greater than the critical values of 1.955020 in absolute term at $5 \%$ level of significant with the $\mathrm{P}$-value of 0.0004 , as a result integrated of the order one $1(0)$.

\section{Post -Hoc Diagnostics \\ Heteroscedasticity Test}

As an important part of linear regression analysis assumptions Heteroscedaaticity test has to be established. Heteroscedasticity test is carried out to establish whether the regression has difference in variance from the residue between observations [19]. This indicates that variance of errors from the residue between observations within the model must be constant.

Table-4

\begin{tabular}{|l|c|c|c|}
\hline \multicolumn{5}{|l|}{ Heteroskedasticity Test: Breusch-Pagan-Godfrey } \\
\hline F-statistic & 0.786579 & Prob. F(4,25) & 0.5448 \\
\hline Obs*R-squared & 3.353529 & Prob. Chi-Square(4) & 0.5005 \\
\hline Scaled explained SS & 13.04445 & Prob. Chi-Square(4) & 0.0111 \\
\hline
\end{tabular}

The White test was conducted for the model as shown above to examine if there is heteroskedasticity problem or not. But since the value of $\mathrm{Obs} * R^{2}$ is 3.353529 with the probability of 0.5005 , the model has no problem of heteroskedasticity, since the p-value is not significant. This means that the study failed to reject null hypothesis which says that residuals are not heteroskedasticity, that is, homoscedasticity. 
Yinka Augustine SOYE \& Omoniyi Oladipupo AGBOOLA; Saudi J Bus Manag Stud, Dec., 2019; 4(12): 898-906

Interpretation of Ordinary Least Square Regression Analysis

Table-4

\begin{tabular}{|c|c|c|c|c|}
\hline \multicolumn{3}{|c|}{ Dependent Variable: LGDP } & & \\
\hline \multicolumn{3}{|c|}{ Method: Least Squares } & & \\
\hline \multicolumn{5}{|c|}{ Date: $11 / 30 / 19$ Time: $11: 00$} \\
\hline \multicolumn{5}{|c|}{ Sample: 19882017} \\
\hline \multicolumn{5}{|c|}{ Included observations: 30} \\
\hline Variable & Coefficient & Std. Error & t-Statistic & Prob. \\
\hline $\mathrm{C}$ & 11.94654 & 0.639618 & 18.67761 & 0.0000 \\
\hline LLPR & 0.223317 & 0.020865 & 10.70276 & 0.0000 \\
\hline LINT & -0.803001 & 0.480617 & -1.670773 & 0.1072 \\
\hline LEXC & 0.061192 & 0.015591 & 3.924912 & 0.0006 \\
\hline LINF & -0.003122 & 0.003618 & -0.862706 & 0.3965 \\
\hline R-squared & 0.903883 & \multicolumn{2}{|c|}{ Mean dependent var } & 12.88708 \\
\hline Adjusted R-squared & 0.888504 & \multicolumn{2}{|c|}{ S.D. dependent var } & 0.872992 \\
\hline S.E. of regression & 0.291501 & \multicolumn{2}{|c|}{ Akaike info criterion } & 0.523466 \\
\hline Sum squared resid & 2.124322 & \multicolumn{2}{|c|}{ Schwarz criterion } & 0.756998 \\
\hline Log likelihood & -2.851983 & \multicolumn{2}{|c|}{ Hannan-Quinn criter. } & 0.598175 \\
\hline F-statistic & 58.77473 & \multicolumn{2}{|c|}{ Durbin-Watson stat } & 1.387962 \\
\hline Prob(F-statistic) & 0.000000 & & & \\
\hline
\end{tabular}

The table 3.6 above presents the least square regression results relating to influence of life insurance business operation income and the economic growth in Nigeria from the 1988 to 2017. The least square regression model's output reveals that three (LEXC \& LLPR) out of the four explanatory variables considered for the study have significant impact on the dependent variable (GDP) individually at $1 \%$ and $5 \%$ level of significance, while the remaining two (LINF \& LINT) have no significant effect on GDP.

Jointly, in the regression analysis the explanatory variables (LEXC, LINF, LINT\& LLPR) considered for the study have really demonstrated their influence on the explained variable (GDP). The Rsquared with the value of 0.903883 reveals the explained variation in GDP by the explanatory variable: interest rate (LINT); exchange rate (LEXC); life insurance premium (LLPR); and inflation rate (LINF). This indicates that the ratios of changes in dependent variable (GDP), which can be attributed to the set of independent variables (LEXC, LINF, LINT \& LLPR) are $90.39 \%$ due to variation of the independent variables analyzed in the model. While the remaining $9.61 \%$ is due to error terms or factors not capture within the model during the analysis. It implies that this model explains large percentage of variations in economic growth in Nigeria through the set of independent variables from 1988-2017, and also represents a good measure of fit. The value of Adjusted R-squared is 0.888504 or $88.85 \%$, being very close to the value Rsquared, is an indication that haven considered the likely error in the model (Error term), that may influence the study's result, the independent variables (LEXC, LINF, LINT \& LLPR) still explained 90.39\%, of variation in dependent variable. The value of Fstatistic (58.77473) with the probability of 0.0000 is significant at $1 \%$ level of significance which indicates that the four explanatory variables: interest rate (LINT); exchange rate (LEXC); life insurance premium (LLPR); and inflation rate (LINF) have jointly, positively and strongly have effect on the Nigeria's economic growth significantly. The DW of 1.387962 indicates that the autocorrelation of the residuals will not pose a problem to the validity of statistical inferences of this research.

$L G D P=a_{0}+L E X C_{\beta 1}+L I N F_{\beta 2}+L I N T_{\beta 3}+L L P R_{4}+\mu \ldots$ In the least square regression above, it reveals that:

$$
\begin{array}{r}
L G D P=11.94654_{0}+0.061192_{\beta 1}+(-0.003122)_{\beta 2} \\
+-0.803001_{\beta 3}+0.223317_{\beta 4}+\mu
\end{array}
$$

In the least square regression above, the intercept line of regression is 11.94654 with the probability of 0.0000 less than $0.05 \mathrm{p}$-value, means that the value is positive and statistically significant, since the p-value is less than $5 \%$; this is an indication that if all independent are held constant at zero, the economic growth (GDP) of Nigeria will be 11.94654 units annually.

\section{TESTING OF HYPOTHESES Hypothesis One}

The coefficient estimated for LEXC is 0.061192 , and the calculated t-value is 3.924912 . According to decision rule, since the estimated coefficient is positive and the calculated t-value is 3.924912 is greater than the t-tabulated value (2.045). The study failed to accept null hypothesis which states that exchange rate has no significant impact on the economic growth (GDP) of Nigeria. And therefore, establish that exchange rate has significant impact on the economic growth (GDP) of Nigeria. 


\section{Hypothesis Two}

The coefficient value of INF1 is -0.003122 , and the calculated t-value is -0.862706 . But since the estimated coefficient is negatively signed and the calculated t-value is -0.862706 is lesser than the $t-$ tabulated value (2.045). The study accepts the null hypothesis which states that Inflation rate has no significant impact on the economic growth (GDP) of Nigeria.

\section{Hypothesis Three}

The estimated coefficient of LINT is 0.803001 , and the calculated t-value is -1.670773 . Since the coefficient value is negative, and the calculated tvalue $(-1.670773)$ is lesser than the $t$-critical value (2.045). The study accepts the null hypothesis which states that interest rate has no significant effect on the economic growth (GDP) of Nigeria.

\section{Hypothesis Four}

The coefficient value of LLPR is 0.223317 , and the calculated t-value is 10.70276. Since the coefficient value is positively signed, and the calculated $\mathrm{t}$-value (10.70276) is greater than the t-critical value (2.045). The study failed to accept null hypothesis which states that life insurance premium (LLPR) has no significant effect on the economic growth (GDP) of Nigeria. The study therefore, establishes that life insurance premium (LLPR) has significant effect on the economic growth (GDP) of Nigeria.

\section{Implication of the Study to the Economy}

From the least square regression model, the coefficient of exchange rate (LEXC) is 0.061192. A unit increase in exchange rate of Nigeria will lead to 6.1 $\%$ increase in GDP if other variables are held constant for the period. This indicates that the exchange rate during the period of the study affected the GDP of Nigeria positively with $6.1 \%$, this may be as a result of mismanagement of other factors such as FDI, Openness, interest rate, and so on, within this period of research.

The regression table- 4 , also shows that the coefficient of inflation rate is -0.003122 with negative sign and not significant because the p-value $(0.3965)$ is greater than $0.05 \%$. Meaning that, a percentage increase in LINF will lead to $0.31 \%$ decreases in the economic growth (GDP) of Nigeria. This indicates that antiinflation economic policies should be intensifying to prevent hyper inflation rate in the economy.

The regression output also reveals that coefficient of interest rate (LINT) is -0.803001 with the probability of 0.1072 . This means that interest rate as at the time of this research is negative and it has no statistically significant to the economic growth (GDP). A unit increase in interest rate will lead to $80.3 \%$ decreases in economic growth (GDP) of Nigeria if other variables are held constant as at this period. This is an indication that INT that high interest rate affected the economic growth (GDP) of Nigeria with $80.3 \%$ negatively during the period of this study. This is a bad sign and negative influence of interest rate on the economic growth of the country. Therefore, the government should review the monetary policies on Nigeria interest rate, basically to ensure price stability and lower interest rate that will stimulate borrowing in the economy.

Finally, the regression table shows that life insurance premium (LLPR) has coefficient of 0.223317 , with the probability of 0.0000 . This implies that during the time of this study LLPR regression value is positive and statistically significant related to economic growth (GDP) of Nigeria. It means that a percent increase in LLPR will lead to 22.33 rises in economic growth (GDP) of the country if other determinant factors are held constant as at this period. This is implies that LLPR as at the time of this study influenced the economic growth (GDP) of Nigeria with 0.223317 or 22.33 percent. This is a positive impact of LLPR on the economic growth of the nation. Therefore, the government should promulgate laws for more compulsory life insurance policies in the economy to increase the patronage of life insurance business in the country, as this will invariably increase life insurance premium, and boost the GDP of the nation.

\section{CONCLUSION AND RECOMMENDATIONS}

This study examined the analysis of the effect of life insurance business operation on the economic growth in Nigeria, taking LEXC, LINF, LINT \& LLPR as explanatory variables, and GDP as control variable. The empirical result establishes that there is significant relationship between LEXC, LLPR \& GDP. However, LINF and LINT have no positive and significant relationship with the economic growth of the country. The preponderance of evidence of our findings shows that exchange rate has really contributed and influences the growth of Nigeria economy. The findings of this study also give credence to the fact that life insurance business has really impacted the economic growth of Nigeria since 1988 to 2017. However, the findings reveal that inflation rate and interest rate have negative relationship with economic growth of the Nigeria during this study. Conclusively, the study submits that life insurance business has significant impact on the economic growth of Nigeria. The study therefore recommends that life insurance business should be given priority among other finance businesses in the country, and government should create a suitable enabling environment for the business by establish laws and make more policies that will compel the insuring public to patronize life insurance coverage.

\section{REFERENCES}

1. Olagbegi, L. (2008). Repositioning the Insurance Industry for a Prosperous Future Insurance. Future Summit 2008, Transcorp Hilton Hotel Abuja. 
2. Agabi, C. (2010). Why Nigerians don't take life insurance.

http://sundaytrust.com.ng/index.php/business/539whynigerians-dont-take-life-insurance. Accessed on 23 January, 2013.

3. Beck, T., \& Webb, I. (2003). Economic, Demographic, and Institutional Determinants of Life Insurance Consumption across Countries. The World Bank economic review, vol. 17, no. 1. Available on https://openknowledge.worldbank.org/bitstream/ha ndle/10986/17169/

4. Madukwe, O. D., \& Anyanwaokoro, D. (2014). The causal relationship between life insurance business and economic growth in Nigeria. Int $J$ Innov Sci Res, 4(2), 100-109.

5. Okpara, G.C. (2006). Capital Market in the Development of Nigeria Economy: An Empirical Analysis. Nigerian Journal of Economic and Financial Research. Vol. 1

6. Ismaila, M., \& Imoughele, L. E. (2015). Macroeconomic determinants of economic growth in Nigeria: A co-integration approach. International Journal of Academic Research in Economics and Management Sciences, 4(1), 34-46.

7. Aliyu, S.R.U. (2011). Impact of Oil Price Shock and Exchange Rate Volatility on Economic Growth in Nigeria: An Empirical Investigation. Research Journal of International Studies.

8. Babalola, O. O., DANLADI, J. D., AKOMOLAFE, K. J., \& AJIBOYE, O. P. (2015). Inflation, interest rates and economic growth in Nigeria. European Journal of Business and Management, 7(30), 91102.

9. Sibindi, A. B. (2014). Life insurance, financial development and economic growth in south africa: an application of the autoregressive distributed lag mode.

10. Hamilton, A. (2001). Exploding Inflation. Zeal Intelligence.

11. Adeniran, J. O., Yusuf, S. A., \& Adeyemi, O. A. (2014). The impact of exchange rate fluctuation on the Nigerian economic growth: An empirical investigation. International Journal of Academic Research in Business and Social Sciences, 4(8), 224.

12. Hossain, M. M. A. (2002). Exchange rate responses to inflation in Bangladesh (No. 2-166). International Monetary Fund.

13. Chichi, O. A., \& Casmir, O. C. (2014). Exchange rate and the economic growth in Nigeria. International Journal of Management Sciences, 2(2), 78-87.

14. Korkmaz, S. (2013). The effect of exchange rate on economic growth: Conference Paper - October 2013

https://www.researchgate.net/publication/3115885 66

15. Chizoba, P. E., \& Nnamocha, P. N. (2018). Effect of Interest Rate on Profit of Insurance Companies in Nigeria. International Journal in Management \& Social Science, 6(7), 233-246.

16. MBOGA, C. K. (2015). The effect of interest rate on financial performance of insurance companies in Kenya. Unpublished MSc project, University of Nairobi.

17. Merton, R. C., \& Bodie, Z. (1995). A conceptual framework for analyzing the financial system, in CRAME. (eds) The global financial system: A functional perspective, 3-31.

18. Okolo, V.C., \& Ani, A.J. (2014). Insurance, Foreign Direct Investment and Economic Growth: Growing the Nigerian Economy through Risk Management. International journal of Innovative Research in Management, 3(6)

19. Obamuyi, T.M. (2009). An investigation of the Relationship between Interest Rates and Economic Growth in Nigeria, (1970- 2006) Journal of Economic and International Finance, 1(4), 093-098.

20. Basler, J. (2012). The moral development and perceptions of academic and clinical integrity of nursing students: An ex post facto study. (Doctoral dissertation). Retrieved from ProQuest Dissertations and Theses. 